\title{
Strategic Entrepreneurial Storytelling: An Applied Framework for Better Pitches
}

\author{
Thomas Martin Key \\ College of Business, University of Colorado Colorado Springs, US \\ E-Mail: tkey@uccs.edu \\ Thomas N Duening \\ College of Business, University of Colorado Colorado Springs, US \\ E-Mail: tduening@uccs.edu
}

\begin{abstract}
Entrepreneurs are responsible for bringing innovative products and services to market. However, in order to bring new value to consumers, most entrepreneurs must secure funding. An integral component in the process of resource acquisition is the entrepreneur's story. Very little research has dealt with the storytelling structure that a good pitch should use. Stories are a fundamental part of the way human beings understand themselves and the world around them. This paper synthesizes the current state of entrepreneurial storytelling and builds a parsimonious framework for strategic entrepreneurial storytelling (SES) through qualitative analysis of actual pitches. Our framework will help entrepreneurs build intentional and compelling stories for their investment pitch through the concepts of SES context, content, and execution.
\end{abstract}

Keywords: Storytelling, Entrepreneurship, Resource acquisition, Investment pitch, Angel investors

\section{INTRODUCTION}

Stories (narrative) are one of the fundamental ways in which humans organize and make sense of their lives and the circumstances around them (Bruner, 1991; McAdams, 1997). Storytelling constitutes a distinct form of communication that is recognizable across cultural and geographic divides and is deemed an innate social skill of the human species (McNeil, 1996; Prince, 1982). Stories we tell ourselves provide us with a sense 
of identity. They allow us to share our identity with others, and they enable a wide range of social interactions and affectivities. Without the richness of storytelling in everyday life, communication would be reduced to explicative reasoning with no affective color or context. Telling stories contextualizes information in a form that engages emotions, provokes communal action, and influences social change. To date, most of the research into storytelling in business has focused on its effects within large, established organizations (Boje, 1991; Boje, 1995; Brown, Denning, Groh, \& Prusak, 2005; Rhodes \& Brown, 2005).

However, there is a growing recognition that storytelling skills and various storytelling opportunities are an integral part of entrepreneurship and the activities involved in venture creation and provide the opportunity for more favorable evaluation by investors (Clark, 2008; Martens, Jennings, \& Jennings, 2007; Middleton, 2013; O'Connor, 2002; Villanueva, Sapienza, \& Sudek, 2013; Wuillaume, Jacquemin, \& Janssen, 2019). Some of this work has demonstrated how the individual entrepreneur's life story provides rich material for theory building to understand how entrepreneurs develop and recognize venture opportunities (Gartner, 2007; Johansson, 2004; Rae, 2004; Rae, 2005; Rae \& Carswell, 2000). Other scholarly work considers the effectiveness of an entrepreneur's ability to use storytelling as a strategic tool for building social capital (Baron \& Markman, 2000), acquiring human and other resources (Clark, 2008; Manning \& Bejarano, 2017; Martens et al., 2007;), venture legitimacy and expectations (Garud, Schildt \& Lant, 2014), and in effecting venture startup (O'Connor, 2002). Despite this emerging research into entrepreneurial storytelling, very little has focused on entrepreneurial storytelling in the context of one of the most vital skills entrepreneurs must learn to master: The investor pitch (Lurtz \& Kreutzer, 2014).

Although recent work has looked at the use of storytelling for finance, there has not been a significant attempt to explain what kinds or how stories are effective (McKensie 2011). Specifically, there has been a dearth of research that provides a comprehensive framework with which entrepreneurs may guide their pitch from its beginning (what kind of information to include) to the actual act (what kind of preparation to present to investors). This paper explores what this framework should consist of and how entrepreneurs can apply it. It is particularly important in becoming an entrepreneur and continuing to pursue an entrepreneurial venture. Access to resources has been shown to positively affect the desire to pursue entrepreneurship, which is a vital source of economic development and job creation and can also influence persistence (e.g., Cheng \& Liao, 2017; Van Scotter \& Garg, 2019).

For addressing this gap, the present work consolidates data gathered from observing 83 investor pitches delivered on the T.V. show Shark Tank, and 15 pitches 
delivered to the Arizona Technology Investor Forum (now Arizona Tech Investors), an angel investor group founded and operated for three years by one of the authors of this paper. We distill key lessons from these diverse pitches and propose a novel and parsimonious framework that informs the essential components of entrepreneurial storytelling in the investor pitch setting. Our framework is condensed into three interlaced pitch components: 1) context, 2) content, and 3) execution. Table 1 summarizes each of these components and how they relate to an entrepreneurial pitch.

Table 1 Components of Strategical Entrepreneurial Storytelling

\begin{tabular}{|l|l|l|}
\hline \multicolumn{1}{|c|}{ Context } & \multicolumn{1}{|c|}{ Content } & \multicolumn{1}{c|}{ Execution } \\
\hline $\begin{array}{l}\text { Made up of sociocultural } \\
\text { and industry knowledge that } \\
\text { articulate fit between } \\
\text { investors and industry. }\end{array}$ & $\begin{array}{l}\text { Made up of credibility, } \\
\text { legitimacy, and competence } \\
\text { to create a story structure } \\
\text { that conveys the personal, } \\
\text { financial, and market } \\
\text { knowledge of the } \\
\text { entrepreneur. }\end{array}$ & $\begin{array}{l}\text { Made up of presentation } \\
\text { skills and flexibility on } \\
\text { behalf of the entrepreneur in } \\
\text { real-time during the pitch. }\end{array}$ \\
& \\
\hline
\end{tabular}

Our strategy for explicating this framework's legitimacy and efficacy begins with a brief review of the scholarship linking storytelling to entrepreneurship. It will clarify that the existing work has not yet examined in detail the use of storytelling in the context of the investor pitch. Next, we briefly review the methodology behind our empirical work and highlight both its strengths and shortcomings. Then we highlight and develop our framework for strategic entrepreneurial storytelling in the context of the investor pitch, including linking our analysis to specific instances. We conclude by offering suggestions for additional research designed to help entrepreneurs devise pitches geared toward facilitating capital investments.

\section{ENTREPRENEURIAL STORYTELLING}

Entrepreneurial storytelling is generally dealt with in two primary ways: 1) as a source to learn more about the entrepreneurial process through the analysis of entrepreneurial life stories (e.g., Johansson, 2004); and 2) as a strategic element in the entrepreneurial toolkit for procuring resources, including investor capital (e.g., Martens et al., 2007; O'Connor, 2002). In the former, the narrative centers on the entrepreneur's life experience as it pertains to opportunity recognition and the startup decision. Such research focuses on entrepreneurial processes, aligning with the general shift in focus from entrepreneurial characteristics to entrepreneurial behaviors aimed at effecting credibility, legitimacy, and managing expectations (Zott \& Huy, 2007; Garud, Schildt, 
\& Lant, 2014). For example, Johansson (2004) demonstrates these features and uses empirical studies to look at how narrative approaches contribute to understanding how entrepreneurs learn and act in a social context. One aspect of social context for the entrepreneur is identity creation, wherein an interview process is a form of narrative, and the entrepreneur is the focus. In this way, the entrepreneur becomes an informant in the ethnographic sense (Bertaux \& Kohli, 1984) and provides keen insight into the meaning and symbols of how to act entrepreneurially (Rae \& Carswell, 2000).

Another aspect of the social context of identity involves the social capital that entrepreneurs develop throughout venture creation (Jonsson, 2015). It consists of the multitudes of embedded relationships that impact the venture creation dynamic (Lee \& Jones, 2015). It is the entrepreneur's investment in network development and the eventual access to superior resources (Adler \& Kwon, 2002). These life-story narratives also include information about the development of everyday practices, which hold insight into gaining legitimacy and the process of learning rules and norms (De Clercq \& Voronov, 2009a; De Clerq \& Voronov, 2009b).

In this light, entrepreneurs are actors who must navigate an ever-changing environment while they seek out and interpret information and build relationships. The life story of entrepreneurs' experiences becomes the backdrop for answering questions about how entrepreneurs learn, recognize opportunity, and take action. It, in turn, is transferred to entrepreneurial education (Rae, 2005; Rae, 2004). This application's entrepreneurial narrative serves as the foundation for exploring a richer and more nuanced analysis to form practical theories that bridge the gap between praxis and generalizability. Through these interviews, researchers often see the results of entrepreneur's ability to tell their stories. Explicit to this paper's topic are stories with specific functionality in moving the entrepreneur forward in their new venture.

O'Connor (2002) suggests a typology of entrepreneurial narratives: personal stories, generic stories, and situational stories. Personal stories reflect the entrepreneur's individual life and aspects of their experience that qualify them as entrepreneurs. Personal stories are essential to the process of establishing personal credibility. They provide data for exploring the relationship between an entrepreneur's personal history and potential access to capital and market opportunities within a competitive landscape where multiple ventures compete for attention (Lounsbury \& Glynn, 2001).

Generic stories center on the nature of the venture and its offerings rather than on the entrepreneur. They are used to position the venture within the competitive space and to articulate its overall strategy and distinctive advantages. Theory building around generic stories is intended to discern how differentiating factors may influence resource acquisition opportunities at the firm level. 
Situational stories position a venture in economic space and time, especially related to the temporal state of the industry in which the venture intends to compete. Manning \& Bejarano (2017) consider the temporal aspects of storytelling in the setting of crowdfunding and identify "strategic moments" that convey past accomplishments and future goals. O'Connor's (2002) work includes historical (near term) and prospective future states of the industry, the state of the market and customer preferences, and adaptations/accommodations that may need to occur. Theory building within this context links macro-scale industry and market trends to the likelihood for ventures to raise capital. For example, ample research has examined the flight of venture capital following the dot-com bust and the resurgence in investing in so-called secondgeneration internet companies. Clearly, industrial, market, and technological factors advanced in the interim in ways that encouraged investors to resume substantial internet venture risk-taking.

In contrast to this research into storytelling as a means of sorting and understanding entrepreneurial prospects and processes, we propose a different perspective that we refer to as "strategic entrepreneurial storytelling" (SES). SES positions the act of storytelling as a deliberate and thoughtful entrepreneurial tool to be deployed in the interest of resource acquisition. Under this perspective, storytelling is construed as an intentional act that has consequences beyond merely being a source of research data. Specifically, we apply SES as an intentional strategic tool for the explicit purpose of securing investor capital via the investment pitch.

Fortunately, SES is an ability that can be developed to strengthen potential resource acquisition. However, it should be noted that a good story cannot make up for a bad idea, poor market opportunity, or lousy leadership/management skills. It can, though, make a good idea, promising market opportunity, and good leadership/management skills stand out and are more compelling to investors. A wellcrafted narrative can become the source of a strategic competitive advantage in the competition for scarce entrepreneurial resources, such as startup capital. Although many ventures may be successful without conscious attention to a strategic story, the absence of a compelling narrative can suggest poor planning or at least create the impression that the entrepreneur has not put a lot of thought into the venture and its prospects (Baker, 2007). 


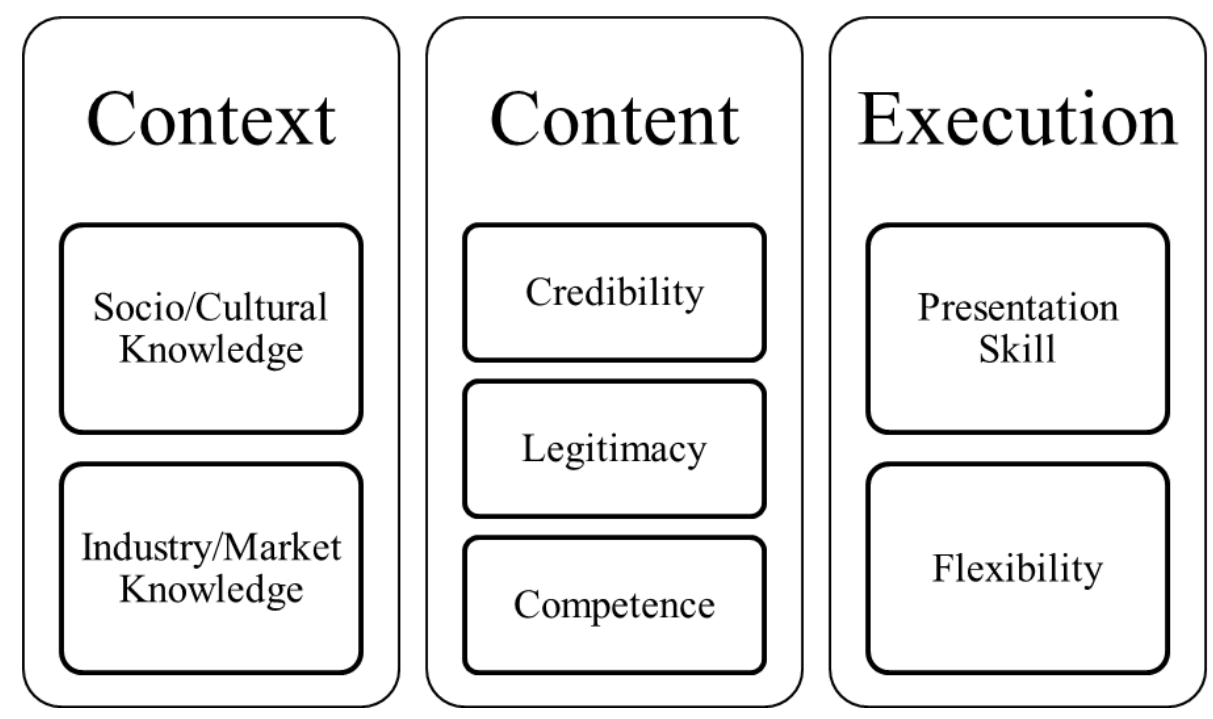

Figure 1. Strategic Entrepreneurial Storytelling Components

\section{RESEARCH METHOD}

The qualitative approach to analyzing real-life entrepreneurial storytelling in the investor pitch context was conducted in two phases. The first phase consisted of the observation and analysis of 83 pitches from the U.S.-based T.V. show Shark Tank, where aspirants pitch their ventures to the high-net-worth "sharks," hoping to win investment. Table 1 summarized the 83 pitches by date, name of the product, and whether it received funding from the investors. The number of pitches was determined by the saturation point (Creswell, 2007) and is in line with recent entrepreneurial storytelling research based on the crowdfunding platform Kickstarter (see Manning \& Bejarano, 2017). Shark Tank was chosen for the first phase of this study for two reasons. The first is that the show requires multiple stages of progression for participants to complete before an episode is filmed with their individual pitch.

In most cases, this means that the participants have been intentional in preparing how they will present their new venture to the investors and represent what they believe will be the most compelling way to "tell their story." It provides an opportunity to assess the "best version" of participants' pitches to analyze effective components. The second reason Shark Tank was chosen as a starting point is the increased performative nature of a television program's pitch. For example, in the relative privacy of a private investor context, for example, a banquet room for monthly pitches, entrepreneurs may be less focused on the polish and embellishment that lends itself to a filmed production. It provides a context of potential exaggeration in which certain aspects of the pitch may stand out and the relative effectiveness more easily identified by observation.

Portions of the pitches were transcribed and analyzed for patterns, that were then discussed as the potential basis of the three SES components based on repeated themes 
(Glaser \& Strauss, 1967). Once the identified components, context, content, and execution were established and agreed upon by expert raters, phase two involved identifying and applying the three SES components in a non-entertainment setting. A second analysis was used is directly related to the foundations for choosing Shark Tank in Phase 1. First, entrepreneurs that were chosen to pitch to the angel investors were pre-screened for their venture growth potential (i.e., not for their camera presence or heartfelt background story). Second, it was important to test if the identified vital story components analyzed from a more theatrical preparation to pitch for a television show would be present in an angel investment group's "more authentic" setting.

Specifically, Phase 2 consisted of fifteen pitches presented to the Arizona Technology Investor Forum (ATIF; now Arizona Tech Investors) over three years from 2006-2009. The expert rater was present at all 15 pitches and analyzed the various pitches as all were video recorded in their entirety. Each pitch consisted of a 20-minute formal pitch by the entrepreneur(s), 20 minutes of live Q/A with the assembled angel investors, and 20 minutes for a due diligence report presented by a member of the angel group. Only the pitch and subsequent Q/A were analyzed for this research. The rater screened out pitches that were unsuccessful in raising capital, leaving five pitches in total to analyze for the vital pitch elements identified in Phase 1.

Below we explore our research findings, revealing the three vital elements of successful investor pitch-related storytelling.

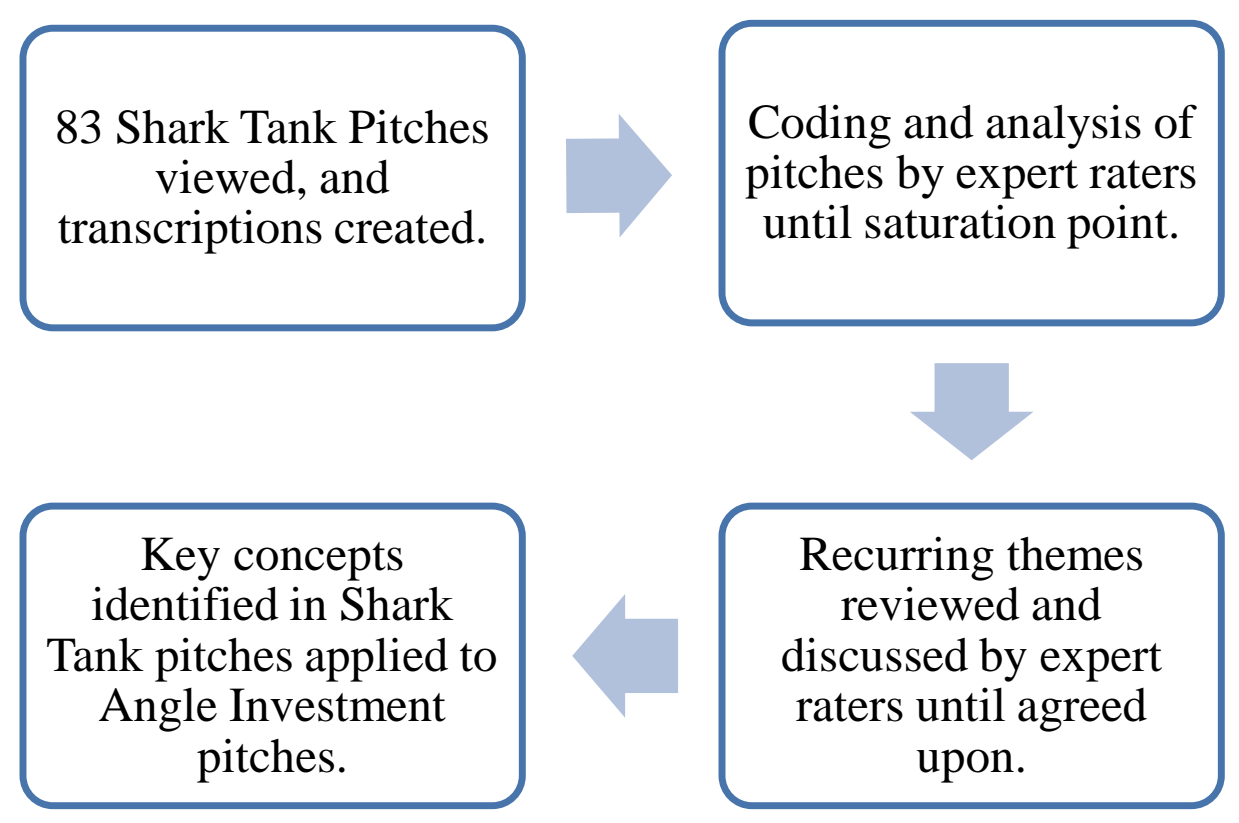

Figure 2 Methodology Summary 


\section{RESULTS: SES APPLIED TO THE INVESTOR PITCH}

The primary application of SES for entrepreneurs is the investor pitch. The investor pitch is defined as the act of communicating the potential of a startup to investors for the express purpose of acquiring capital. However, to the extent it appears in the literature, entrepreneurial storytelling is associated chiefly with personal, generic, and/or situational stories and their translation into practical lessons for greater effectiveness in entrepreneurial processes, such as opportunity recognition and the venture initiation decision. Very little work has been done to determine the role of strategic entrepreneurial storytelling (SES) in practical, applied settings, such as the allimportant investor pitch.

Given the paucity of research into entrepreneurial storytelling as a strategic tool for resource acquisition (Lurtz \& Kreutzer, 2014) a framework of SES for the investor pitch will help formalize an overlooked component of this vital area of entrepreneurial practice. Careful viewing of 83 pitches on the television show resulted in threecomponent of our framework, which was then applied in a second context that was not associated with the entertainment industry. These were made up of 15 pitches to the Arizona Technology Investor Forum. We chose to apply the concepts originally identified in the T.V. show in a non-entertainment context to help create more validity that may have been problematic given the nature of television editing that may have created blind spots for our observations. The resultant concepts that make up our framework are context, content, and execution.

Context refers to those aspects of the entrepreneurial story that articulate the fit between the new venture's products and the existing industry, shared values and norms between investors and the entrepreneur, and the investors' respective backgrounds and motives such as their industry background and expertise. Content involves the structure of the story that is told during the pitch and the organization of significant personal, financial, and market knowledge. Execution refers to the entrepreneur's ability to enact and interpret aspects of contextual and content information in real-time. Critically, this storytelling component centers on improvising, reading the audience, and adapting content and context components accordingly. Without the ability to execute effectively, contextual understanding and high-quality content can be dramatically ineffective.

The investor pitch occurs when an entrepreneur meets with potential investors for the express purpose of influencing them to decide on capital investment. Therefore, a strategic story can be essential in creating such influence. To advance the potential for a successful pitch, the entrepreneur intentionally has to craft the relevant context, compelling content, and socially adapted execution of their story to make the most of what can be a defining moment for their venture. Below, we consider each of these key SES components in more detail. 


\section{SES Context}

Context is the component of the framework that is concerned with helping investors in their sense-making process. Context gives SES its foundation and proper orientation. Entrepreneurs need a series of large contextual frames of reference combined with specific details to effectively communicate relevant information, data, and knowledge to potential investors. In our SES framework, the investor-pitch storytelling context begins with helping investors understand how the venture fits within the past, present, and potential future states of the industry and market. Attention to how these historical and prospective factors relate to the particular interests/experiences of the investors is crucial. Of course, previous knowledge of investor backgrounds may not be possible to ascertain in advance of a pitch. However, to the extent there are cues present during the pitch, during Q\&A, for instance, an entrepreneur may need to adjust the context of the story in real-time to address those factors of most concern to the investors. This ability to adapt in real-time is further addressed in SES execution below.

The story presented in the investor pitch also must be positioned within established, pertinent, and logical culturally-specific language and phrases. For example, the pitch should deploy common jargon, symbols, or other sources of specific business knowledge that is shared between the entrepreneur and investors (Hardy, Palmer, \& Phillips, 2000; Martens et al., 2007). Examples of common generic knowledge include business model, value proposition, and differentiating unfair advantage. Such culturespecific knowledge aligns the story with pre-existing stories, experiences, and lore that investors use to make sense of investment opportunities. The SES must be positioned concerning this ongoing story to create a juxtaposition that allows the entrepreneur to present the proposed venture as unique enough to establish innovation yet familiar enough to capture investor's interest and support (Lounsbury \& Glynn, 2001; Martens et al., 2007).

SES context also sets the stage for the entrepreneur to demonstrate understanding of the particular nature and value of their specific venture concerning the marketplace and with the potential investors to whom they are pitching. It requires the entrepreneur to link their story's contextual components deliberately through rigorous analysis of cultural understanding and those factors that may be of interest to investors. SES context represents the proverbial landscape in which the entrepreneur must be oriented adequately so that the terrain's details may be appropriately structured and organized. For example, when sisters Rachael Mann and Mackenzie Burdick pitched their custom jewelry designs on Shark Tank, they already knew they wanted to work with Daymond John and Mark Cuban (two of the show's "Sharks") because of specific background expertise in the fashion industry and technology (Shark Tank, 2012). The sisters' SES 
context included their knowledge of the niche culture in the high-end custom jewelry business and working with celebrities and museum exhibition pieces. This perfectly aligned with John's deep knowledge and experience in the fashion industry. They also articulated a need for better website and digital marketing, which spoke to Cuban's high-tech background. Even though the sisters were getting other and potentially higher offers, they chose to take the deal with John and Cuban because they knew the fit between their background and the expertise and experience of John and Cuban would be superior.

One common way of establishing context is through the deployment of one or more exemplar use cases. A use case is simply a vivid description of how the venture's offerings will impact a particular customer segment's lives. Steve Jobs famously established the use case for the first iPhone by teasing the audience into understanding how they will no longer need to possess an iPod, Internet communicator, and phonethey would all be combined in a single new device. The crowd went wild.

In a live pitch setting to the Arizona Technology Investor Group, the context was the predominant component of a comprehensive pitch offered by a Flypaper startup. Flypaper's pitch needed to emphasize context because its offering was new to most of the assembled investors. As noted in the context case study, several use cases were critical in convincing the investors to back the venture.

\section{Case Study: Context}

Flypaper Raises \$1M in 24 Hours

One of the more successful pitches to the Arizona angel group was delivered by a company formerly known as Flypaper. Flypaper had developed a unique technology that enabled companies to design and develop e-learning courses from a desktop computer. A takeoff of desktop publishing, desktop e-learning was in its nascent stages when Flypaper presented its pitch.

Given that no one of the assembled angels had ever heard of desktop e-learning, it was vital for the Flypaper pitch to focus on the technology context. Of course, the pitch included an overview of the technology and its capabilities, and the pitch also had much style in its execution (the pitch presenter was a seasoned serial entrepreneur).

Still, given that there was little awareness of the technology space and even less awareness of its market potential, developing the market context was imperative. To develop the context in detail, the pitch focused on two different factors: 1) The immense 
success and corporate penetration of desktop publishing; and 2) The need for rapid deployment of low-cost e-learning solutions for certain types of mission-critical applications.

The first factor, the success of desktop publishing, was well known to most of the assembled angels. Desktop publishing was introduced to the corporate environment in the mid-1980s, over 20 years before the 2007 Flypaper pitch. Thus, the pitch included an overview of the pace of that technology's diffusion and uptake into the corporate environment. It also included a review of the companies' success, such as PageMaker, that led the industry in the early days.

With this context established, Flypaper had a more difficult time establishing the context of desktop e-learning since it was a new construct. To address this, the pitch centered on specific use cases where rapid deployment of corporate-wide e-learning would be exceedingly valuable. One such case is a new product introduction. Often in the course of new product introduction, companies encounter unexpected customer reactions and pushback. Rather than outsource training to a learning design company, a more rapid response is to manage the issue with in-house developed training.

A second use case centers on crisis management and employee engagement. In the midst of a crisis - even a minor one-it is often helpful for companies to keep employees informed and trained on appropriate responses and mitigation initiatives. An in-house, desktop e-learning platform is invaluable when rapid communication and training are required to manage an emerging crisis.

This context-heavy pitch turned out to be one of the more successful pitches to the Arizona angel investor group. Within 24 hours of the pitch, Flypaper had received pledges totaling nearly $\$ 1$ million, effectively closing their funding round. Since then, the company has been acquired by Trivantis, Inc., a Cincinnati-based e-learning solutions provider.

\section{SES Content}

If context represents the landscape of the entrepreneurial story, then content makes up the various landmarks and Spatio-temporal details that are crucial in the process of establishing credibility (Lounsbury \& Glynn, 2001), legitimacy (Martens et al., 2007; O'Connor, 2002), and competence (MacMillan, Siegel, \& Subba Narasimha, 1985). It is accomplished by formatting specific pertinent information established through the 
understanding of SES context. In other words, once the SES context has been established, content informs and determines specific details that make up the body of the story. Content, therefore, can be made up of germane personal and situational details (O'Connor, 2002) that speak to salient features of the entrepreneur's personal history, the industry of interest, proposed marketplace, target market, and other details germane to investor decision making (Clark, 2008).

Content includes both what the entrepreneur only intends to include in the story to investors and what they are prepared to share during the pitch's performance if circumstances warrant. For example, depending on the dynamics of the give-and-take during the pitch and the level of interest shown by investors, the entrepreneur may need to account for shortcomings, go deeper into their personal history, or even improvise solutions they had not previously considered. It requires the entrepreneur to draw on the specific content developed during pitch preparation. For example, when Jeff Wolsky pitched to Shark Tank investors about a business that makes custom bobblehead dolls to be located in malls and amusement parks, he had not planned on sharing details about a pre-existing and quite profitable online version of the same business that he also owns (Shark Tank, 2009a). To his dismay, the investors were much more interested in his existing and already profitable business than the untested version he came to pitch-a situation and scenario Wolsky was not prepared to discuss. In addition, once investors were informed about the existing business, they were unsupportive of the new venture, suggesting a lack of perceived legitimacy in the original pitch. One investor actually felt betrayed after discovering that Wolsky owned another business and it was not part of the venture on offer- effectively implying a lack of focus. Wolsky had not gauged adequately how his new venture fits with his existing business, nor the potential for what may constitute the investor's interest. It effectively derailed the pitch for his new venture and negotiation for investment in his existing company, which ended with "no deal."

In the case of iMemories, a focus on content was a determining factor in the Arizona Technology Investor Forum pitch. Founder Mark Rukavina created an energizing emotional mood among the investors by highlighting how boxes full of precious family memories stored on outdated media rapidly was deteriorating. As the content case study notes, Rukavina succeeded with the investors by weaving a story that appealed to each investor's knowledge of how precious such memories can be. 


\section{Case Study: Content}

\section{iMemories Pitch Content Weaves a Compelling Value Proposition}

When Mark Rukavina pitched his iMemories venture to the angel group he became the poster child for effective interweaving of context and content (his execution was pretty good too). Mark began his pitch by carefully establishing an emotional connection to his business. He pointed out that every medium heretofore devised to capture priceless family memories was prone to deteriorate. To illustrate his point, Mark brought along a prop - one that is not uncommon to most families, including the families of the angels assembled to hear his pitch. The prop that so dramatically illustrated his venture's value was a box full of old photos, video and audiotapes, and various reel-based videos. All of this content-family weddings, births, graduations, and more-deteriorated in closets and attics across the country.

Mark's simple prop was able to weave the emotional value of what his new service will bring to customers and conveyed the immense market opportunity and the technical prowess of his venture. No other company had yet mastered the ability to mass-process this wide variety of memorialized content. Mark was going to disrupt what had been a cottage industry, and he was going to do so with proprietary software and processes that he had already created.

Mark supplemented this folksy-level content with a precise articulation of the market opportunity, the competitive landscape, and the likely exit opportunities available to his venture. He presented the results of his processes on what at the time was a state-of-theart Apple smartphone. Since many of the angels were not yet users of this technology, the display of family videos, photos, and memories on the vivid mobile screen was impressive. More, Mark clearly delineated his market position and provided insight into the sophisticated technology that enabled him to create a processing "factory" that could handle massive volumes of content.

Finally, Mark indicated that he had invested a substantial sum of his own money in getting the venture to the point it was at the time of the pitch. He also noted his success with previous ventures in the high technology space. The result of his pitch was an offer from the angel group within 24 hours. Alas, Mark's pitch was so compelling that a previous investor decided to double down on his investment, taking the entire round that Mark had presented to the angel group. His pitch is proof positive that the content of a pitch can massively motivate sophisticated investors to open their wallets. 


\section{SES Execution}

SES execution is essential in tying together well-thought-out context and informed content by providing the necessary skill set to clearly and effectively tell the story. This concept has been touched upon in the form of pitch presentation (Clark, 2008), impression management (Baron \& Markman, 2000; Mason \& Harrison, 2003), and practice (De Clercq \& Voronov, 2009a; De Clercq \& Voronov, 2009b). At the core of execution are an understanding and conscious awareness that the way the entrepreneur and the pitch are perceived is a function of knowing basic pitch techniques and how to adapt and make spontaneous adjustments on the fly. For example, research into what angel investors look for in a pitch demonstrates that they pay close attention to the style, quality, focus, structure, and clarity of presentations (Clark, 2008; Mason $\&$ Harrison, 2003). These presentation features impact the process angels use when deciding whether to follow up on investment opportunities. Despite the positive effects that storytelling as a whole can have on the way a new venture is perceived by investors, a poorly executed presentation can lead investors to interpret underlying deficiencies in the entrepreneur (Mason, 2006; Villanueva, Sapienza, \& Sudek, 2013).

Poor execution means more than just the vocal or technical components of the pitch. It can also include the dress and mannerisms of the presenter. In the execution case study, we look at how Arizona Technology Investor Forum investors missed out on an opportunity because they misjudged the venture based on the presenter's relatively disheveled and youthful appearance.

\section{Case Study: Execution}

\section{Youthful Appearance Scuppers an Investment}

Investors pay attention to things beyond the words, numbers, and graphics that are used to convey the investment opportunity, occasionally in error. One example of this occurred when a group of young entrepreneurs from the University of Arizona (U.A.) pitched their ATIF idea. The venture was named "Notehall". The basic concept behind the venture, which was already deployed at U.A., enabled students to post their class notes online for others to purchase and use for studying. The platform they had created also enabled customers to rate the notes and notetaker's value, which enabled customers of the platform to gauge the value of their purchase.

Notehall had already passed the rigorous pre-screening process used by the angel group to narrow the field of ventures allowed to pitch to the entire group. Each quarterly 
meeting entertained just three pitches (usually out of a field of 20-30 applicants). Thus, the screening committee clearly recognized the value of the venture, allowing it to be pitched at the quarterly meeting.

A young student delivered the pitch from U.A., who was one of the founders of the venture. While he conveyed basically the same information to the entire group conveyed successfully to the screening committee, other factors in the execution led to a negative decision among the group as a whole. The young man conducting the pitch was dressed in a suit that looked to be about two sizes too big for starters. The amusement among the group regarding the disheveled, youthful appearance of the presenter was evident. In addition, the presenter did not parry well with the group during the question and answer session, further encouraging a general sense of an undermanaged venture.

While this outcome was not a good one for Notehall, it turns out the decision not to invest ended up being a worse outcome for the angel group. Within a year of the failed pitch, Notehall was invited to participate in one of the leading accelerator programs in the United States. Following that experience, the company continued to grow and eventually was acquired by the educational services company Chegg.

Just as important as the planned presentation is the ability to go in unexpected directions if needed. Social perception and adaptability allow entrepreneurs to gauge the affective state of other people, change attitudes, and exude social competence in a wide variety of situations (Baron \& Markman, 2000). These are skills that allow the entrepreneur to develop a structured pitch while keeping the wider story malleable to adapt to emerging twists and turns that may arise during an investor pitch. For example, during the structured pitch, the entrepreneur may need to skip to more pertinent aspects of their story depending on the body language, vocal tone, and how closely the investors are paying attention. If the story appears not to capture the investor's interest, that may be a signal to skip the biographical or personal part of the story and go directly to the market research, financial projections, or estimated return on investment. Likewise, if the entrepreneur perceives signs of disbelief or hesitation, they may need to change narrative direction to address emerging, real-time concerns. For example, when Jonathon Miller pitched his business for a website that makes custom energy bars, the investors' resistance to it was very strong (Shark Tank, 2009b). At one point, they claimed it was an idea easy to imitate and claimed his valuation of the company absurd. However, through a skillful execution of his story and a change in his narrative focus, specifically the story content, he effectively managed to turn what was quickly 
becoming a bad pitch into one the investors were interested in and thus left with a great investment deal.

Another instance, though an extreme case, occurred when Darren Johnson pitched his invention for a surgically embedded Bluetooth device (Shark Tank, 2009c). During the pitch, he did very little to head off growing and visibly bemused investors over safety and design concerns. All of the sharks made less than subtle references about the safety of a Bluetooth device surgically inserted below the ear that would need to be plugged in an A.C. adaptor to charge. However, Johnson made no efforts to restructure or adapt his story's execution to address these concerns. He also did nothing to demonstrate or expand on the safety features designed into the product. Though his idea may have had its own limitations, he could have done much to try and restructure his story at the moment of the pitch to address the investors' concerns.

An entrepreneurial story's execution during an investment pitch captures the end game of performing the narrative when it matters most. If context and content are the proverbial landscape and landmarks, then execution is the vehicle to travel to entrepreneurial destinations. Together, these three constructs sum up various contributions made about storytelling in the entrepreneurial literature and offer a parsimonious theoretical construct for developing strategic entrepreneurial stories to acquire human and venture capital.

\section{CONCLUSION}

For innovative products and services to make it to market, engaging and deliberate storytelling must be enacted by entrepreneurs to capture the interest and resources of investors. We have referred to this as strategic entrepreneurial storytelling (SES) and have discovered three distinct and essential components to successful SES: context, content, and execution. These three essential elements provide a valuable and efficient framework for SES in the investor pitch setting. Entrepreneurs can use the framework by addressing and tailoring each component for their specific stage of resource acquisition to strengthen and focus their efforts and efficacy. Specifically, the framework's simple structure provides a template that entrepreneurs can use to develop and deliver intentional and powerful stories that resonate with early talent acquisition and financial investors. Stories are at the heart of capturing and communicating both the potential for the venture and the entrepreneurial team's capabilities. Paying attention to content, context, and execution does not guarantee the investor pitch will result in a successful raise. However, given that investors are generally seen as in control of the pitch setting (the vaunted "golden rule") our research goes some way to tip the balance of power in a small way back to the risk-taking entrepreneur. 


\section{REFERENCES}

Adler, P.S., \& Kwon, S.W. (2002). Social capital: Prospects for a new concept. The Academy of Management Review, 27(1), 17-40. https://doi.org/10.5465/amr.2002.5922314

Baker, T. (2007). Resources in play: Bricolage in the Toy Store(y). Journal of Business Venturing, 22(5), 694-711. https://doi.org/10.1016/j.jbusvent.2006.10.008

Baron, R.A., \& Markman, G.D. (2000). Beyond social capital: How social skills can enhance entrepreneurs' success. Academy of Management Executive, 14(1), 106116. https://doi.org/10.5465/ame.2000.2909843

Bertaux, D., \& Kohli, M. (1984). The life story approach: A continental view. Annual Review of Sociology, 10(1), 215-237.

https://doi.org/10.1146/annurev.so.10.080184.001243

Boje, D.M. (1991). The storytelling organization: A study of story performance in an office-supply firm. Administrative Science Quarterly, 36(1). https://doi.org/10.2307/2393432

Boje, D.M. (1995). Stories of the storytelling organization: A postmodern analysis of Disney as "Tamara-Land." The Academy of Management Journal, 38(4), 9971035. https://doi.org/10.5465/256618

Brown, J.S., Denning, S., Groh, K., \& Prusak, L. (2005). Storytelling in Organizations: Why Storytelling is Transforming 21st Century Organizations and Management. Burlington, MA: Butterworth-Heinemann.

Bruner, J. (1991). The narrative construction of reality. Critical Inquiry, 18(1), 1-21. https://doi.org/10.1086/448619

Cheng, L. J., \& Liao, C. C. (2017). The drivers of entrepreneurial intention: The role of social capital and overconfidence. Contemporary Management Research, 13(2) ,143-162. https://doi.org/10.7903/cmr.17589

Clark, C. (2008). The impact of entrepreneurs' oral 'pitch' presentation skills on business angels' initial screening investment decisions. Venture Capital, 10(3), 257-279. https://doi.org/10.1080/13691060802151945

Creswell, John W. (2007), Qualitative Inquiry \& Research Design: Choosing Among Five Approaches. Thousand Oaks: Sage Publications, Inc.

De Clercq, D., \& Voronov, M. (2009a). Toward a practice perspective of entrepreneurship: Entrepreneurial legitimacy as habitus. International Small Business Journal, 27(4), 395. https://doi.org/10.1177/0266242609334971

De Clercq, D., \& Voronov, M. (2009b). The role of cultural and symbolic capital in entrepreneurs' ability to meet expectations about conformity and innovation. 
Journal of Small Business Management, 47(3), 398-420.

https://doi.org/10.1111/j.1540-627x.2009.00276.x

Gartner, W.B. (2007). Entrepreneurial narrative and a science of the imagination.

Journal of Business Venturing, 22(5), 613-627.

https://doi.org/10.1016/j.jbusvent.2006.10.003

Garud, R., Schildt, H. A., \& Lant, T. K. (2014). Entrepreneurial storytelling, future expectations, and the paradox of legitimacy. Organization Science, 25(5), 14791492. https://doi.org/10.1287/orsc.2014.0915

Glaser, B.G., \& Strauss, A.L. (1967). The Discovery of Grounded Theory: Strategies for Qualitative Research. Chicago, IL: Aldine Publication CO.

Hardy, C., Palmer, I., \& Phillips, N. (2000). Discourse as a strategic resource. Human Relations-New York, 53(9), 1227-1247.

https://doi.org/10.1177/0018726700539006

Johansson, A.W. (2004). Narrating the entrepreneur. International Small Business Journal, 22(3), 273-293. https://doi.org/10.1177/0266242604042379

Jonsson, S. (2015). Entrepreneurs' network evolution - the relevance of cognitive social capital. International Journal of Entrepreneurial Behavior \& Research, 21(2), 197-223. https://doi.org/10.1108/ijebr-09-2013-0147

Lee, R., \& Jones, O. (2015). Entrepreneurial social capital research: resolving the structure and agency dualism. International Journal of Entrepreneurial Behavior \& Research, 21(3), 338-363. https://doi.org/10.1108/ijebr-02-2014-0025

Lounsbury, M., \& Glynn, M.A. (2001). Cultural entrepreneurship: Stories, legitimacy, and the acquisition of resources. Strategic Management Journal, 22(6-7), 545564. https://doi.org/10.1002/smj.188

Lurtz, K., \& Kreutzer, K. (2014). What does your audience expect from you? How entrepreneurs acquire resources through storytelling. Academy of Management Annual Meeting Proceedings, 2014(1). https://doi.org/10.5465/ambpp.2014.85

MacMillan, I.C., Siegel, R., \& Subba Narasimha, P.N. (1985). Criteria used by venture capitalists to evaluate new venture proposals. Journal of Business Venturing, 1(1), 119-128. https://doi.org/10.1016/0883-9026(85)90011-4

Manning, S., \& Bejarano, T. A. (2017). Convincing the crowd: Entrepreneurial storytelling in crowdfunding campaigns. Strategic Organization, 15(2), 194-219. https://doi.org/10.1177/1476127016648500

Martens, M.L., Jennings, J.E., \& Jennings, P.D. (2007). Do the stories they tell get them the money they need? The role of entrepreneurial narratives in resource acquisition. The Academy of Management Journal, 50(5), 1107-1132.

https://doi.org/10.5465/amj.2007.27169488

Mason, C.M. (2006). Informal sources of venture finance. In Parker S. (Ed.), 
The Life Cycle of Entrepreneurial Ventures (Vol. 3, pp. 259-299). Boston, MA: Springer. https://doi.org/10.1007/978-0-387-32313-8_10

Mason, C.M., \& Harrison, R.T. (2003). Auditioning for money: What do technology investors look for at the initial screening stage?. Journal of Private Equity, 6(2), 29-42. https://doi.org/10.3905/jpe.2003.320037

McAdams, D.P. (1997). The Stories We Live By: Personal Myths and the Making of the Self. New York, NY and London: The Guilford Press

McNeil, L.D. (1996). Homo inventans: The evolution of narrativity. Language and

Communication, 16(4), 331-360. https://doi.org/10.1016/s0271-5309(96)00025-0

Middleton, K.L.W. (2013). Becoming entrepreneurial: Gaining legitimacy in the nascent phase. International Journal of Entrepreneurial Behavior \& Research, 19(4), 404-424. https://doi.org/10.1108/ijebr-04-2012-0049

O’Connor, E. (2002). Storied business: Typology, intertextuality, and traffic in entrepreneurial narrative. Journal of Business Communication, 39(1), 36-54. https://doi.org/10.1177/002194360203900103

Prince, G. (1982). Narrative analysis and narratology. New Literary History, 13(2), 179-188. https://doi.org/10.2307/468908

Rae, D., \& Carswell, M. (2000). Using a life-story approach in researching entrepreneurial learning: The development of a conceptual model and its implications in the design of learning experiences. Education + training, 42(4/5), 220-228. https://doi.org/10.1108/00400910010373660

Rae, D. (2004). Practical theories from entrepreneurs' stories: Discursive approaches to entrepreneurial learning. Journal of Small Business and Enterprise Development, 11(2), 195-202. https://doi.org/10.1108/14626000410537137

Rae, D. (2005). Entrepreneurial learning: A narrative-based conceptual model. Journal of Small Business and Enterprise Development, 12(3), 323-335. https://doi.org/10.1108/14626000510612259

Rhodes, C., \& Brown, A.D. (2005). Narrative, organizations and research. International Journal of Management Reviews, 7(3), 167. https://doi.org/10.1111/j.1468-2370.2005.00112.x

Shark Tank (2009a). Episode 110. https://abc.go.com/shows/shark-tank/episodeguide/season-1/10-episode-110

Shark Tank (2009b). Episode 106. https://abc.go.com/shows/shark-tank/episodeguide/season-1/6-episode-106

Shark Tank (2009c). Episode 101. https://abc.go.com/shows/shark-tank/episodeguide/season-01/101-episode-101

Shark Tank (2012). Episode 308. https://abc.go.com/shows/shark-tank/episodeguide/season-03/308-episode-308 
Van Scotter, J. R., \& Garg, S. (2019). Entrepreneurial Tenacity and Self-Efficacy Effects on Persisting Across Industry Contexts. Contemporary Management Research, 15(3), 147-173. https://doi.org/10.7903/cmr.19501

Villanueva, J., Sapienza, H. J., \& Sudek, R. J. (2013). Does it matter how you tell it? How entrepreneurial storytelling affects the opportunity evaluations of earlystage investors. Frontiers of Entrepreneurship Research, 33(19), 1.

Wuillaume, A., Jacquemin, A., \& Janssen, F. (2019). The right word for the right crowd: An attempt to recognize the influence of emotions. International Journal of Entrepreneurial Behavior \& Research, 25(2), 243-258.

https://doi.org/10.1108/ijebr-10-2017-0412

Zott, C., \& Huy, Q.N. (2007). How entrepreneurs use symbolic management to acquire resources. Administrative Science Quarterly, 52(1), 70-105. https://doi.org/10.2189/asqu.52.1.70

Dr. Thomas Martin Key (Corresponding author) is an associate professor of Digital Strategy \& Marketing at the University of Colorado Colorado Springs. His research primarily deals with digital and strategic marketing issues at the executive level and the study of marketing's role in the firm. He is a Daniels Ethics Initiative Fellow and Cybersecurity Fellow and frequently works with new startups as well as established firms to help them create plans to grow and create value for their customers.

Dr. Thomas Duening is the El Pomar Chair for Business \& Entrepreneurship, and Associate Professor of Management at the University of Colorado Colorado Springs. His current research interests are in entrepreneurship education, cognitive science, and the predictive brain. His most recent book, Technology Entrepreneurship: Taking Innovation to the Marketplace was published by Academic Press in December 2020. 
Appendix Shark Tank Sample Data

\begin{tabular}{|c|c|c|c|c|c|}
\hline Date & Venture & Funded & Date & Venture & Funded \\
\hline \multirow{5}{*}{ 9-Aug-09 } & Mr. Tod's Pie Factory & Yes & 20-Oct-09 & The Bobble Place & No \\
\hline & Ionic Ear & No & & Mr. Poncho a poncho & No \\
\hline & Wispots & No & & Uroclub & Yes \\
\hline & Ava the Elephant & Yes & \multirow{4}{*}{ 8-Jan-10 } & Romp n' Roll & No \\
\hline & $\begin{array}{l}\text { College Foxes Packing } \\
\text { Boxes }\end{array}$ & No & & Hells Bells a helmet & Yes \\
\hline \multirow{5}{*}{$\begin{array}{l}\text { 16-Aug- } \\
09\end{array}$} & Crooked Jaw & No & & $\begin{array}{l}\text { The Twister a golf ball } \\
\text { cleaner }\end{array}$ & No \\
\hline & Lifebelt & No & & The Chef in Black & Yes \\
\hline & A Perfect Pear & Yes & \multirow{4}{*}{ 15-Jan-10 } & The Factionist & No \\
\hline & Sticky Note Holder & No & & Podillow & No \\
\hline & Classroom Jams & Yes & & Wee Can Shop & No \\
\hline \multirow{5}{*}{$\begin{array}{l}\text { 23-Aug- } \\
09\end{array}$} & Turbobaster & Yes & & Grease Monkey Wipes & Yes \\
\hline & Kwyzta Chopstick & No & \multirow{4}{*}{ 29-Jan-10 } & Lipstix Remix & Yes \\
\hline & Stress Free Kids & Yes & & Captain Ice Cream & No \\
\hline & $\begin{array}{l}50 \text { State Capitals in } 50 \\
\text { Minutes }\end{array}$ & No & & Caffeindicator & Yes \\
\hline & Voyage Air Guitar & No & & Legal Grind & No \\
\hline \multirow{5}{*}{$\begin{array}{l}\text { 30-Aug- } \\
09\end{array}$} & Gift Card Rescue & Yes & \multirow{4}{*}{$5-F e b-10$} & $\begin{array}{l}\text { Send A Ball greeting } \\
\text { balls sent in the mail }\end{array}$ & No \\
\hline & NoSoul's Calling & No & & $\begin{array}{l}\text { Qubits a bendable } \\
\text { construction toy }\end{array}$ & Yes \\
\hline & Coffee Brand Gifts & No & & Pillars of Slippers & No \\
\hline & $\begin{array}{l}\text { Graffiti Removal } \\
\text { Services }\end{array}$ & No & & $\begin{array}{l}\text { Llama Brew liquid } \\
\text { llama fertilizer }\end{array}$ & No \\
\hline & Coverplay & Yes & 20-Mar-11 & $\begin{array}{l}\text { Wurkin Stiffs } \\
\text { magnetic collar-stays }\end{array}$ & Yes \\
\hline \multirow{5}{*}{ 6-Sep-09 } & Body Jac & Yes & \multirow{5}{*}{ 25-Mar-11 } & Copa di Vino & No \\
\hline & Granola Gourmet & No & & $\begin{array}{l}\text { Toygaroo a toy } \\
\text { subscription service }\end{array}$ & Yes \\
\hline & $\begin{array}{l}\text { Good Grief Celebrations } \\
\text { a funeral concierge } \\
\text { service }\end{array}$ & No & & Wake n’ Bacon & No \\
\hline & Face Blok & No & & $\begin{array}{l}\text { Vurtego extreme pogo } \\
\text { sticks }\end{array}$ & No \\
\hline & My Therapy Journal & Yes & & $\begin{array}{l}\text { First Defense Nasal } \\
\text { Screen a personal air } \\
\text { filtration system }\end{array}$ & Yes \\
\hline \multirow{4}{*}{$\begin{array}{l}\text { 13-Sep- } \\
09\end{array}$} & $\begin{array}{l}\text { Element Bars float that } \\
\text { screws onto soda bottles }\end{array}$ & Yes & 8-Apr-11 & $\begin{array}{l}\text { Ride-On Carry-On } \\
\text { luggage }\end{array}$ & Yes \\
\hline & Pork Barrel BBQ & Yes & \multirow{3}{*}{ 22-Apr-11 } & $\begin{array}{l}\text { Caddy Swag drink } \\
\text { cooler }\end{array}$ & No \\
\hline & $\begin{array}{l}\text { The Fizz a reinvention of } \\
\text { the root beer }\end{array}$ & No & & Daisy Cakes & Yes \\
\hline & $\begin{array}{l}\text { Underease Underwear } \\
\text { protective underwear for } \\
\text { flatulance }\end{array}$ & No & & Hydromax & Yes \\
\hline
\end{tabular}




\begin{tabular}{|c|c|c|c|c|c|}
\hline & $\begin{array}{l}\text { Kalyx a line of sports } \\
\text { bras }\end{array}$ & No & \multirow{2}{*}{ 29-Apr-11 } & Oragaudio & Yes \\
\hline \multirow{4}{*}{$\begin{array}{l}\text { 29-Sep- } \\
09\end{array}$} & Grill Charms & Yes & & Man Candles & No \\
\hline & $\begin{array}{l}\text { FunHouse an } \\
\text { entertainment venue }\end{array}$ & No & \multirow{3}{*}{ 6-May-11 } & HyConn & Yes \\
\hline & Boogie Box Fitness & No & & CitiKitty toilet training & Yes \\
\hline & Soy-Yer-Dough & Yes & & One Sole & Yes \\
\hline \multirow{4}{*}{ 6-Oct-09 } & Notehall & Yes & \multirow{2}{*}{ 13-Мay-11 } & $\begin{array}{l}\text { I Want To Draw A Cat } \\
\text { For You }\end{array}$ & Yes \\
\hline & Treasure Chest Pets & Yes & & Show No towel & Yes \\
\hline & $\begin{array}{l}\text { Throx a company that } \\
\text { sells socks }\end{array}$ & No & 27-Jan-12 & Kisstixx lip balm & Yes \\
\hline & Washed Up Hollywood & No & $10-F e b-12$ & Show No towel & Yes \\
\hline \multirow{4}{*}{ 13-Oct-09 } & Chill Soda a healthy soda & Yes & 2-Mar-12 & Litter a line of jewelry & Yes \\
\hline & Cornucopia & No & & & \\
\hline & VirtuSphere & No & & & \\
\hline & Gayla Bentley Fashion & Yes & & & \\
\hline
\end{tabular}

